\title{
Stakeholder Theory and Accounting
}

The Cambridge Handbook of Stakeholder Theory (2019) / edited by Jeffrey S. Harrison, Jay B. Barney, R. Edward Freeman, Robert A. Phillips [9781108123495]

Chapter 11, p. 173-188

\section{Samantha Miles, Oxford Brookes University}

This chapter reviews the extent to which stakeholder theory has been applied to, and adopted within, the academic accounting literature. The influence of stakeholder theory on accounting is growing but lags behind other business disciplines. This is due to the prevailing dominance of the shareholder primacy paradigm and a lack of convergence between the epistemological structure and socio-cultural characteristics of accounting, with university and professional education lagging behind contemporary thinking. This chapter starts with a discussion of these factors to provide context.

The academic field of accounting is vast, and spans various distinct, yet overlapping, fields. This review is based on three sub-disciplines: management accounting (internal control and decision-making), financial accounting (reporting to external stakeholders) and sustainability reporting. Finance, auditing and corporate governance are not included. The review is restricted to the 27 accounting journals identified as $3^{*}$ or $4^{*}$ in the ABS Journal Ranking List (2015) and the Journal of Management special issue (52:7) on accounting for stakeholder value. The review is organized by sub-discipline and structured around prevailing themes.

Considering the widespread appeal of stakeholder theory there is surprisingly little application to accounting research. The majority of research identified focused on two applications of stakeholder theory: i) as an explanation for reporting content of financial statements or sustainability reporting; ii) as a means of widening the remit of the accounting function beyond shareholder primacy. For the majority of papers reviewed, however, the research is framed within stakeholder terminology and discourse but does not adhere to the tenets of stakeholder theory. Conclusions 
suggest that there exists a strong opportunity to advance accounting through more novel, and more in-depth, applications of stakeholder theory. Accounting directly impacts stakeholders through the manner in which claims are recognized, recorded and prioritized. Influencing accounting to report on ways that are more relevant to stakeholders presents a clear opportunity for mainstreaming stakeholder theory and for enhancing the usefulness of the accounting function.

\section{The Socio-Cultural Characteristics of Accounting}

Accounting is a cultural artefact which serves an important social welfare function in wealth distribution. Perry and Nölke (2006: 560) argued that 'Accounting impacts the lives of everyone in society, even (or perhaps especially) those who know very little about the subject and have never set eyes on a financial statement'. Accounting policy choice has economic consequences as accounting numbers determine, to varying extents, the price paid for goods by consumers, wage rises, bonuses and investments in staff, corporate taxation contributions to society, shareholder returns and pension actuary rates. The impact of accounting choice can be widespread. For example, fair value accounting (FAS157), enacted in 2006 by FASB in the USA which updated asset and liability values for banks, was highlighted by Laux and Leuz (2009) as a key determinant in the 2008 financial crisis.

Anglo-American accounting is predominantly self-regulated by the accountancy profession. Standard setting bodies retain independence but are subject to significant political pressure from the vested interests inherent. The corporate and investor voice are the dominant pressures, as shareholders have historically provided the prevailing source of corporate finance. This influences the nature of standards issued and the objective of reporting which is skewed towards meeting the needs of 'investors, lenders and other creditors in making decisions about providing resources to the entity' (IASB, 2010:OB2). The needs of other stakeholders are either ignored or assumed to be included within this objective. This extends to sustainability reporting, despite the perception of this information being aimed at a wider audience, as evident in the Integrated Reporting Framework and the Sustainability Accounting Standards Board framework which focus on 'providers of financial capital' and 'investors' respectively (Ringham and Miles, 2018). 
Hines (1988) advocated that the social influence of accounting is so strong that accountants 'create reality' (of what is accepted as valuable in business) by constructing the reality of what is recognized, measured and accounted for. For financial accounting this is restricted to those items in which a monetary value can be assessed with a reasonable degree of certainty. The boundary of reporting is based on ownership, control and significant influence within the definition of the legal entity. This determines what is, and, is not considered to be part of the organization and therefore what activities are reasonable to expect an organization to report on. This limits reporting to significant direct impacts of operations over which the organization has control (including subsidiaries), but excludes medium and long-term indirect impacts on ecosystems and society which may be of interest to a wider stakeholder audience. To exacerbate this issue Archel, Fernández, and Larrinaga (2008) argued that the financial reporting boundary is generally adopted within sustainability reporting. Alternative forms of investment, such as social, environmental or human capital are ignored, together with any return on capital derived, or associated distribution of value. This is considered poor strategic management (Freeman, Harrison, Wicks, Parmar and de Colle, 2010) and leads inequity in the distribution of value.

Despite dramatic changes in the business world and 'a barrage of business scandals' leading to 'a crisis of legitimacy' for the accounting profession (Fisher, Swanson and Schmidt, 2007), accounting education has not progressed (Albrecht and Sack, 2000). Moral development is considered to be poor for both accounting students (Gray, Bebbinton and McPhail, 1994) and professional accountants (Armstrong, 1987). Many accounting firms have experienced detrimental consequences for their involvement in accounting frauds, the most high profile being the collapse of Arthur Andersen LLP in 2001 following the fraudulent handing of the Enron audit. Whilst the fall out of scandals and corporate collapses have damaging financial impacts on shareholders it is often the wider group of stakeholders that are most seriously affected, both at the individual (psychologically, socially and financially) and societal levels (increased unemployment and social benefits bill).

Albrecht and Sack (2000) suggested that there is a greater need to take account of 
the interests of different stakeholders across academic and professional accounting education. The solution to date has not, however, emerged. Accounting bodies have a long history of accrediting higher education programmes whereby the syllabi is tailored to the syllabi of professional exams in exchange for offering professional exam exemptions to students. This affords the accounting bodies a substantial amount of power over shaping module content, which is significantly more pronounced compared to other disciplines. Furthermore, the extent to which the

syllabi of the major accounting bodies embrace the stakeholder approach is weak, reflecting the dominant political pressures. This is, consequently, reflected throughout many degree programmes.

\section{The Epistemological Origins of Accounting}

Accounting is a sub-discipline of economics with the origins of its epistemological elements traced to the neo-classical economic framework. Historically accounting was created to record the financial aspects of organizations, but within the AngloAmerican system soon developed into a corporate monitoring mechanism to protect capital providers against managerial self-interest, abuse and fraud. Accounting also serves as a bonding mechanism designed to increase goal congruence through the construction of contracts tied to accounting ratios. For example, corporate debt covenants tied to leverage levels and managerial bonuses and share plans determined by profit, earnings per share or total shareholder return.

Traditional Anglo-American accounting theory reflects corporate law and is based on the theory of property rights and the maximization of shareholder wealth, presumed to be synonymous with the maximization of the value of the firm (Clarke, 2014). Little consideration is given to stakeholder interests beyond their impact on shareholder wealth or to elements (assets, liabilities, capital, revenues and expenses) that cannot be measured in monetary terms. This contrasts sharply with, for example, accounting in Finland which is seen as a means of providing information to satisfy the needs of a wide range of stakeholders (Näsi and Näsi, 1996). The work of Rhenman has heavily influenced Finnish university education in accounting, which draws on the capital circulation and stakeholder models and incorporates social, environmental, public sector and not-for-profit disclosure as part of the mainstream accounting function. 
Anglo-American accounting research has focused on the development of shareholder-centric models resulting from the intricate power relations that enshrine the importance of shareholders over other groups in society. 'The theoretical underpinnings of the subject are restricted to only one 'subset' of ethical reasoning: financial utilitarianism.....which is, in a sense, "indoctrination" (Ferguson, Collison, Power and Stevenson, 2005: 24). Parker (2007) argued that the historic influences from economics and finance-based positivism has led to accounting research being largely uncritical of the role of accounting in i) accepting the demands of the financial markets; ii) questioning the need to engage in reform via addressing major policy questions, and; iii) reporting for a broader range of stakeholders. Cooper and Owen (2007) called for legal reform towards a pluralistic form of governance to remove the one-dimensional power afforded to shareholders. Further lobbying of the profession is also warranted. Hawley (1991) argued that if shareholder wealth maximisation is continually prioritised as the superordinate goal, accounting academics are abdicating their responsibility to encourage corporate managers to recognize and deal with stakeholder inclusiveness effectively.

Whilst shareholder primacy remains the predominant paradigm there has been various attempts in accounting research that have questioned this, and it is this subject that the discussion now turns. Partial reviews of the application of stakeholder theory to accounting exist (e.g. Brown and Jones, 2015; Freeman et al., 2010; Roberts and Mahoney, 2004) but there is further scope for a comprehensive, systematic review in this area.

\section{Financial Accounting}

Considering the widespread appeal of stakeholder theory there is surprisingly little research that has focused on a stakeholder theory approach to financial accounting. The majority of research within this stream relates to the exploration of stakeholder influence on financial disclosure and stakeholder information needs. There is also some exploratory research on stakeholder-oriented accounting systems. These will be considered in turn. 


\section{i) Stakeholder Influence on Accounting Information}

Accounting disclosure is determined in the first instance by regulators, such as standard setters and, in the second instance by corporate management. AngloAmerican accounting studies recognise that standard setting is a mixed power system with stakeholders viewed as external social and political forces which pressurize standard setters and organizations to select accounting policies that satisfy their interests (Kwok and Sharp, 2005). This was illustrated by Nobes (1991): Upward force for tighter regulation, stemming from government, international influences, the profession and the media, are countered by demonstrable downward pressures for flexible standards from corporations.

Stakeholder theory has been used as a framework to explain corporate earnings management, particularly with respect to earnings quality (the selection of more conservative accounting policy choices) and the timing of earnings announcement under management discretion. Thomson (1993) provided an early example through an analysis of stakeholder power during the pre- and post-privatization of the UK electricity industry. Pre-privatization focus of primary stakeholder groups (government, consumers, competitors) on rates of return incentivized management to minimize profits to avoid price-capping, whereas post-privatization profitmaximizing accounting choices were selected, as management were incentivized by newly constructed bonus and share option contracts to align their interests with those of the recently created shareholders. In a similar vein, Bowen, DuCharme and Shores (1995) found that implicit claims between an organization and its customers, suppliers, employees and short-term creditors act as incentives for management to use long-run income-increasing accounting choices in relation to depreciation and inventory. The use of a socio-economic perspective to evaluate accounting policy choice, as explored in such studies, provides a richer, more inclusive explanation of behaviour than reference to economic theories alone (Mangos and Lewis, 1995).

Scott, McKinnon and Harrison (2003) examined the historical assessment (18571975) of stakeholder influence on the 'cash-based versus accruals' accounting choice at two Australian hospitals. Stakeholder influence was found to be a 
determinant of accounting choice if stakeholders possessed power to exert influence and an incentive to exercise that power. Earnings management practices were found to differ between stakeholder-oriented countries and shareholder-orientated countries, with individuals from the former being less tolerant of earnings management due to the perceived impact on multiple stakeholder groups (Geiger and van der Laan Smith, 2010).

Mattingly, Harrast and Olsen (2009) argued that stakeholder management is an effective process for governing organizations as it is associated with higher levels of accountability and higher earnings quality. Their findings clearly indicated that companies with more effective stakeholder management followed more conservative accounting choices and had more transparent financial disclosure, thereby meeting a wider range of stakeholders' needs. Likewise, Hui, Klasa and Yeung (2012) illustrated that suppliers and customers with a bargaining advantage influence the selection of more conservative accounting policies. Such stakeholders bear significant downside risks if an organization fails but gain little from strong corporate performance.

A 'stakeholder hypothesis' was developed by Bowen, Johnson, Shevlin and Shores (1992) to explain how organizations may benefit from timing the earnings announcement. The conceptualization of stakeholder theory was taken from the accounting and finance literature (citing Cornell and Shapiro, 1987). They argued that managers have an incentive to minimize the adverse reaction of stakeholders to bad news by delaying related earnings announcements. Building on this Burgstahler and Dichev (1997) argued that firms with higher earnings face lower transaction costs: consumers will pay a premium for assurance that warranties will be honoured, and suppliers/lenders offer better terms if repayment is more certain. They reasoned that implicit claims act as incentives for management to select accounting choices that maximise profits/minimise losses.

Drawing on the 'proactive-accommodative-defensive-reaction' organizational strategy model and the life-cycle model (citing Jawahar and Mclaughlin, 2001), Camara, Chamorro and Moreno (2009) examined how the amount and type of financial information in the annual reports of the tobacco industry varied over the period 1887-1986 depending on the interests and power of key stakeholder (the State, employees and society). One area where stakeholder theory is repeatedly 
used (in conjunction with legitimacy theory and agency theory) is within the voluntary disclosure of intellectual capital (see for example Alcaniz, Gomez-Bezares and Roslender, 2011; Castilla-Polo and Gallardo-Vázquez, 2016; Leuz and Verrecchia, 2000, and; Yongvanich and Guthrie, 2005). Disclosure is dealt with within traditional balance sheet measures but can be supported by non-financial metrics and narrative, as, for example, developed in the Danish Intellectual Capital Statement (Nielsen, Roslender and Schaper, 2017). Beattie and Thomson (2007) and Beattie and Smith (2012) offered a managerial stakeholder perspective (disclosure driven by demands of primary stakeholders) and ethical stakeholder theory perspective (responsibility-driven disclosure) to explain motives for voluntary disclosure. They concluded that whilst the needs of financial market participants were paramount, the media and consumers were influential in disclosure decisions, especially disclosures that aimed to avoid scrutiny from stakeholder groups.

\section{ii) Accounting Information Needs of Stakeholders}

The objective of financial reporting, closely associated with user information needs, has been heavily contested by the accounting profession. Two objectives have dominated this debate: economic decision-making (aligned to shareholder primacy) and stewardship (more aligned to stakeholder theory). Early regulation (e.g. US Securities Act, 1933; US Securities Exchange Act, 1934; UK Corporate Report, 1975) mandated the provision of reports for stewardship in the first instance and economic decision-usefulness information as a secondary objective. The current international conceptual framework (IASB, 2010) has regressed. Stewardship has been replaced by economic decision-making, thereby reinforcing the shareholder primacy paradigm (Harrison and van der Laan Smith, 2015).

There is widespread criticism of the nature of financial reporting for reinforcing shareholder primacy and failing to meet stakeholder needs. Murphy, O'Connell and Ó hÓgartaigh (2013), for example, contended that stewardship is central to the 'living law' of accounting and is fundamental to encouraging corporate decision-makers to broaden their responsibilities. Barsky, Hussein and Jablonsky (1999) also called for richer disclosure to encompass a societal balanced score card approach. A wheel of stakeholder interests' was presented and stakeholder theory was discussed (citing Woodward et al., 1996 and Langtry, 1994). They argued that financial reporting 
practices contributed to the selection of a poor downsizing strategy at United Technologies Corporation that favoured shareholders over other stakeholder groups.

A stewardship approach to reporting will result in greater levels of disclosure as transparency is fundamental in discharging stewardship. This is particularly important for public sector reporting and several papers have explored this area from a stakeholder theory perspective. Goddard and Powell (1994) criticised the usefulness of public sector accounting systems in improving services due a misalignment between the shareholder wealth creation model followed in the reporting of public goods (determined by financial and legal probity) and lack of consideration of the plurality of stakeholder claims, concerns, issues, values and needs. Their 'naturalistic stakeholder evaluation' concluded that greater levels of stakeholder consultation were needed to understand how stakeholders use accounting information. This sentiment was echoed by Ellwood (2009) and Tooley, Hooks and Basman (2010). Ellwood (2009) applied the ladder of stakeholder engagement (Friedman and Miles, 2006) to analyse public healthcare in the UK. Tooley et al., (2010) highlighted the need to balance the multiple interests of stakeholders. They observed differences between the perceptions of internal and external stakeholders on the relative importance of disclosure items in the public sector reports.

The stakeholder salience model (Mitchell, Agle and Wood, 1997) has also been applied to explore financial reporting user needs (e.g. Kamal, Brown, Sivabalan and Sundin, 2015). Specific applications included analysis of the response of the accounting profession to a crisis of credibility following an embezzlement scandal in New Zealand (Baskerville-Morley, 2004) and to assess public perception of profits during a period when the social reputation of the Canadian banking industry was sullied (Breton and Côté, 2006).

\section{iii. Alternative financial reporting systems}

Current financial reporting systems are considered deficient with regards to stakeholder inclusiveness (Mitchell, Van Buren, Greenwood and Freeman, 2015). This impedes the adoption of stakeholder theory within management practice and has led to calls for the reconceptualization of the accounting function. A special 
issue of the Journal of Management Studies, dedicated to accounting for stakeholder value, addresses such concerns. Harrison and van der Laan Smith (2015) criticized the approach adopted by standard setters, calling for a reversal of the narrowing of the accounting function to widen the objectives towards accountability and stewardship. Brown and Dillard (2015) proposed a governance-focused solution that advocated a move beyond the managerial ethos to reflect a more pluralistic dialogue within accounting. For the remaining contributors the solution recommended was less radical. Hall, Millo and Barman (2015) supported the calculation of a stakeholder orientated social return on investment whilst both Crane, Graham and Himick (2015) and Andon, Baxter and Chua (2015) proposed adaptation of the current system. Crane et al. (2015) argued that pension accounting already provides metrics needed to co-ordinate stakeholder claims, through the accommodation of the time, security and priority aspects of the claims of pension beneficiaries. Shaoul (1998) provided a much earlier illustration of how financial reports can be used to assess the distribution of value to consumers, employees, industry and the public. The guest editors (Mitchell, Van Buren, Greenwood and Freeman, 2015) detailed a pragmatic stakeholder value creation accounting model that required a conscious shift away from the organization-centric entity concept of financial reporting to a proprietary concept model to capture value creation and risk sharing through the recording of exchange activities. They acknowledged that their ideas represented a sketch of a complex process, calling for further research in this emerging area.

In summary the financial accounting research stream has acknowledged that stakeholder theory provides a richer, more inclusive explanation of behaviour compared to economic theories in examining stakeholders influence on standard setting, earnings management and voluntary disclosure. Stakeholder theory provides convincing explanations of management incentives to manage stakeholder pressure, to minimise information asymmetry, decrease transaction costs, reduce unwanted scrutiny from stakeholders and, to legitimise actions following reputation breaches. Research indicates that the adoption of a strategic stakeholder orientation results in greater levels of accountability, higher earnings quality, higher levels of voluntary disclosure and the adoption of more conservative accounting policies. The resulting increase in predictability and reliability of earnings has palpable societal benefits for stakeholders. 
There remains, however, significant scope to explore financial reporting from a stakeholder theory perspective. Relatively little is known about how stakeholders influence accounting disclosure, particularly outside of the public sector. Whilst most papers within this research stream view the organization as a nexus of stakeholder contracts, stakeholder models are rarely adopted or tested, offering potential avenues for future research. Opportunities also exist to develop alternative financial accounting systems, along the lines of Mitchell et al., (2015), which aim to question the fundamental structure of existing financial reporting provision. Further research is thereby required to make stronger theoretical connections between stakeholder inclusiveness and the reporting function.

\section{Management Accounting}

Studies that examine the influence of stakeholder theory in management accounting are focused in the area of control and performance management. Kaplan and Norton (2001) are very clear that the balanced score card (BSC) is not a stakeholder scorecard aligned to corporate strategy. They claimed that a focus on stakeholder interests fails to reflect the causal relations between strategic areas and that the 'balance' relates to the balancing of outcomes, not stakeholder interests. Nevertheless there have been a number of articles that have evaluated the BSC from a stakeholder theory approach. Sundin, Granlund and Brown (2010) questioned Kaplan and Norton's assertion that stakeholder and strategy scorecards are mutually exclusive in a capitalist system. The BSC was revised to a "balancing scorecard' which started with a systematic identification of multiple stakeholders interests before implementing a traditional BSC analysis of the perceived cause-andeffect relationships and trade-offs between objectives and measures. The challenges that a stakeholder theory approach raises for resource allocation, performance measurement and achieving an equitable balance of interests were acknowledged by Sundin et al. (2010) but their conclusions clearly supported a focus on the balancing process to achieve procedural justice.

Stakeholder analysis was also considered beneficial in understanding the dynamic influences of the external and internal environments on the formulation of objectives and strategy in a study by Li and Tang (2009). They provided empirical support for Jensen's (2001) enlightened stakeholder theory with respect to the application of a 
BSC. Axa and Bjørnenak (2005) found that Swedish corporations clearly implemented the BSC in a stakeholder orientation manner that aligned with the Swedish stakeholder capitalism model. This form of capitalism recognises implicit long-term bonds with stakeholders and is based on a system of mutual trust and cooperation.

The influence of stakeholder theory on management control research was not evident until the publication of Norris and O'Dwyer (2004). Stakeholders are increasingly concerned with how corporate social and environmental issues are measured, monitored and reported suggesting the need for management to consider and weigh stakeholders' concerns when selecting key performance indicators (KPIs) (Dillard and Roslender, 2011). Combining stakeholder theory with resource dependency theory, Länsiluoto, Järvenpää and Krumwiede (2013) found that buy-in was more achievable if goal congruence between stakeholders and resource providers was achieved in setting stakeholder objectives. This requires the explicit identification of stakeholder expectations and the subsequent translation of these expectations into specific accounting performance indicators. They found evidence of stakeholder influence in the selection of KPIs. This reflected the findings from Brignall and Ballantine (2004): stakeholders negotiate proposals for change and use power and conflict to influence managerial choice of performance measures.

Durden (2008) presented case evidence to demonstrate that a management control system that explicitly considered stakeholder goals would clearly differentiate management's efforts to operate in a socially responsible manner from public relations exercises. Stakeholder influence on the selection of environmental KPIs was also investigated by Rodrigue, Magnan and Boulianne (2013). Stakeholder influence ranged from i) mediated influence on environmental strategy; ii) indirect influence from explicit stakeholder pressures on environmental KPIs selection; iii) shared influence arising from a common mind-set for environmental improvement, and; iv) environmental benchmarking influence, stemming from a comparison of performance by stakeholders to corporate peers.

Other papers referred to the stakeholder model but did not base the analysis undertaken around it (e.g. Carlsson-Wall, Kraus and Messner, 2016). Merchant 
(2006) explicitly rejected stakeholder theory as a framework but recognized that there could be some benefit if applied in a stakeholder-oriented not-for-profit setting. There is very limited research that investigates management accounting problems from a stakeholder theory perspective, providing clear opportunities for future research.

\section{Sustainability Reporting}

Within the sustainability reporting literature stakeholder theory is viewed as an overlapping, complimentary theory to legitimacy theory, set within a political economy framework (Gray et al., 1995). This overlap is frequently mentioned (e.g. Cormier, Magnan and Van Velthoven, 2004), supported (e.g. Thorne, Mahoney and Manetti, 2014) but rarely questioned (e.g. Tilling and Tilt, 2010). The predominant stakeholder perspective adopted is a strategic, instrumental theory approach.

Gray, Dey, Owen, Evans and Zadek (1997) contended that stakeholder theory has only limited use as a lens for evaluating motives for disclosure, in so far as it helps to define which stakeholder groups management deem important, and in doing so identifies the boundaries of responsibility that organizations are willing to accept. They argued that the stakeholder perspective, being organization-centric, assumes that stakeholder interests are subsumed within the interest of management and therefore results in flawed, partial and biased reporting. This sentiment was echoed by Adams and Whelan (2009) and Parker (2005) who likened instrumental stakeholder theory to corporate enlightened self-interest driven by corporate strategic aims.

Normative stakeholder theory, which is often referred to as the accountability variant of stakeholder theory within the accounting literature, is considered to have little descriptive power within a sustainability reporting context (Gray, Owen, and Adams, 1996). The ongoing discussion in the stakeholder theory literature on the validity of the separation of ethics from actions that implies that instrumental (strategic) stakeholder theory can be applied separately from normative (ethical) stakeholder theory is largely ignored in the accounting literature as most researchers accept separation (Oriji, 2010). 
There have, nevertheless, been some attempts at looking at wider accountability within a stakeholder perspective (e,g. O'Dwyer, Unerman and Bradley, 2005). Williams and Adams (2013) proposed an 'intrinsic' stakeholder approach, likened to that adopted in the AccountAbility AA1000 series and based on inclusivity, materiality, and responsiveness. This framework combined normative stakeholder theory with the theories of legitimacy, political economy, and the role of language and rhetoric in order to consider the moral responsibilities corporations have to employees, including the discharge of accountability evident in sustainability reporting.

Most sustainability reporting research is organisation-centric and focused on economic stakeholders such suppliers, customers, lenders, competitors and investors (Mahadeo, Oogarah-Hanumana and Soobaroyen, 2011; Islam and Deegan, 2008). Few authors, such as Momin (2013), focused on a stakeholdercentric perspective, or a wider range of non-commercial stakeholders, despite the concern that it important for research to capture marginal voices. Notable exceptions are Deegan and Blomquist (2006), O'Dwyer et al., (2005), O'Dwyer, Unerman and Hession (2004; 2005), Tilt (1994) and, Unerman and O'Dwyer (2006), who examined NGOs and, Grosser and Moon (2008) who explored gender equality reporting.

Research can be categorized into two streams which are now discussed in turn: i) stakeholder theory as an explanation for voluntary disclosure, ii) stakeholder engagement in the sustainability reporting process.

\section{i) Voluntary Disclosure}

Stakeholder theory was first suggested as a framework for explaining voluntary disclosure by Ullmann (1985). The logic is straightforward: stakeholders demand sustainability information, and those with power to influence the corporation, derived from their control of critical resources, are more likely to have their demands met. Subsequent disclosure is the mechanism by which conformance to stakeholder expectations is demonstrated (Moneva and Llena, 2000). Ullmann (1985) cited the seminal contribution of Freeman's (1984) generic stakeholder strategies and Pfeffer 
and Salancik's (1967) discussion on power and resource dependency. These theories were combined in the development of a three dimensional 'contingency framework' for implementing sustainability issues that considered stakeholder power, strategic posture and economic performance. This framework has empirical support in the accounting literature (e.g. Magness, 2006; Prado-Lorenzo, Gallego-Alvarez, and Garcia-Sanchez, 2009). Roberts (1992) found significant relationships between stakeholder power, strategic posture, economic performance and levels of disclosure across 130 major corporations, particularly with respect to government and creditor relationship management. More recently Herbohn, Walker, and Loo (2014) found sustainability reporting was significantly associated with media coverage, disposable resources and heightened exposure to environmental costs, thereby concluding that Ullmann's framework remains relevant in explaining voluntary disclosure.

Closely related to the issues of resource dependency and power is the notion of stakeholder salience. Researchers have provided empirical support for the proposition that the level and quality of sustainability reporting is positively correlated to stakeholder salience (see Dong, Burritt and Qan, 2014; Soobaroyen and Ntim, 2013). Orij (2010) and Van der Laan Smith, Adhikari and Tondkar (2005) also found that power, legitimacy and urgency attributes of stakeholders are more pronounced in an international context and that stakeholder theory offers plausible explanations for variations in sustainability disclosure across countries. Van der Laan Smith et al. (2005) explored institutional and cultural differences between American and Norwegian/Danish organizations operating in the electric power generation industry. Their proposition that stakeholder theory provides a useful explanation for observed international differences was further tested by Van der Laan Smith, Adhikari, Tondkar and Andrews (2011) through the creation of a six point stakeholder scale to determine stakeholder/shareholder orientation. This tool captured issues such as perceptions of corporate social responsibility (CSR), the willingness to sacrifice return for improved CSR performance, and perceptions of the corporate objective function. They confirmed the earlier finding that stakeholder theory provided a proficient lens to evaluate and explain the systematic cross-national differences in investor responses to sustainability reporting.

Pérez, López and García-De los Salmones (2017) also supported the explanatory 
powers of the salience model in their empirical application to Spanish companies and recommended the establishment of regular stakeholder salience monitoring mechanisms as part of the reporting process. Brennan and Merkl-Davies (2014) adapted the salience model to incorporate the role of rhetoric skill in achieving conflict resolution in sustainability reporting. Rhetoric skill in harnessing stakeholder support from environmental activists, consumers, the general public and the media, was considered to be more effective in attaining power than direct control of financial resources. They tested their model on the interaction between Greenpeace and six sportswear/fashion firms over the elimination of hazardous chemicals within supply chains. Greenpeace's success in this endeavour was attributed to its rhetoric skills in coalition-building and political action.

Accounting research examining stakeholder influences on voluntary sustainability reporting has been fairly limited (e.g. Deegan and Blomquist, 2006 and Leisen, Hoepner, Patten and Figge, 2015). Elijido-Ten (2008) fully embraced stakeholder theory in an application of Frooman's stakeholder influencing strategy framework to the issue of how stakeholder demands for sustainability reporting are attended to. The inconclusive results were considered to be a consequence of a lack of urgency in the focal event studied, leading to a subsequent re-examination in the context of an urgent issue which had potential significant negative stakeholder impacts (ElijidoTen, Kloot and Clarkson, 2010). They concluded that stakeholder theory is useful in understanding both stakeholder and managerial behaviour with respect to sustainability reporting.

Elijido-Ten (2011) also applied Freeman's stakeholder strategy framework to voluntary sustainability reporting decisions. Her analysis juxtaposed the potential of a comprehensive range of stakeholders (consumers, media, government agencies, suppliers, shareholders, creditors, competitors, environmentalists and employees) to co-operate, against their potential to threaten organization process. She identified real and significant opportunities for some groups (government and consumers) to pressurize corporates into addressing environmental concerns and disclosing impact.

Leisen et al. (2015) provided an extensive empirical study of greenhouse gas (GHG) 
emissions disclosure using a stakeholder theory framework. They established alternative hypotheses to explain GHG emission disclosures of 431 companies. The first hypothesis suggested stakeholder driven disclosure, given the increased importance assigned to GHG emissions for climate change and associated stakeholder pressure to conform. The second hypothesis was based on disclosure as a legitimating strategy, given that GHG disclosure is largely voluntary and subject to managerial capture and manipulation. They found support for both arguments and evidenced stakeholder influence on GHG emission reporting.

\section{ii) Stakeholder Engagement}

There are a multitude of papers which explore the role of stakeholder engagement in the sustainability reporting process (e.g. Deegan and Rankin, 1997; Tilt, 1994). Stakeholder engagement offers increased accountability to powerless and marginalized stakeholders and is linked to good governance, increased long-term value and reduced reputational and operational risks (Barone, Ranamagar and Solomon, 2013; Miles, Hammond and Friedman, 2002). Stakeholder engagement is a means of managing disclosure and it dominates the professional sustainability reporting arena such as the Global Reporting Initiative and AccountAbility AA1000 series.

Most contributors adopt stakeholder terminology but do not rigorously base their analysis on stakeholder theory (see Calabrese, Costa and Rosati, 2015). Boesso and Kumar (2009), Connolly, Hyndman and McConville (2013) and Manetti and Bellucci (2016) are all examples of papers that do place stakeholder theory explicitly within their analysis. Boesso and Kumar (2009) investigated the stakeholder prioritization and engagement process, associated with stakeholder salience (Mitchell et al., 1997) through an empirical assessment of US and Italian practice. Their findings highlighted the practical difficulties and limitations involved in meeting the needs of multiple stakeholder groups, despite managerial desires to address stakeholder demands. Despite astronomic increases in social media use, Manetti and Bellucci (2016) found that only a small minority of the 332 corporations examined actively used social media for stakeholder engagement and that the level of interaction was low. Social media can be effective in providing a voice to a wide range of stakeholders but Manetti and Bellucci (2016) warned that this may be 
deceptive if the democratic process is not embedded. Connolly, et al. (2013) highlighted the problems of involving stakeholder groups meaningfully in a consultation process and, like Manetti and Bellucci (2016) highlighted the danger of quasi-consultation being undertaken to generate buy-in rather than to action influence in their study on the UK charity accounting standard setting process. They concluded that although funders were identified as legitimate primary stakeholders their influence was fairly negligible in determining content and disclosure.

In summary the largest impact that stakeholder theory has had on accounting research has been in the area of sustainability reporting (Gray Kouhy and Lavers, 1995). This research is predominantly organisation-centric. There remains significant scope to engage with stakeholder theory in a more robust way as the majority of research whilst framed within stakeholder terminology and discourse lacks systematic application (Spence, Husillos and Correa-Ruiz, 2010).

\section{Conclusions}

This review has outlined a growing body of accounting research that embraces stakeholder theory. There are two dominant areas in which stakeholder theory has been used as a frame of reference. Firstly, as an explanatory theory for accounting choice and voluntary disclosure the implicit claims of powerful stakeholders are considered. This enriches understanding by providing plausible explanations for anomalies that cannot be explained through traditional economic theories, such as agency theory. Stakeholder theory is also applied in exploring stakeholder influence, focusing on the identification of stakeholders needs and addressing how reporting can best fulfil these needs (or not).

Significant future research opportunities still exist. Firstly researchers can learn from the application of stakeholder theory in other disciplines. Whilst there are some exceptions, for example the multiple applications of the salience model (Mitchell et al., 1997), there is generally a notable lack of acknowledgement of seminal stakeholder theory contributions originating from outside of the accounting literature. This indicates that further interdisciplinary research could provide useful insights into accounting problems and enhance understanding of management behaviour 
regarding the accounting function.

Secondly, more robust and explicit theoretical analysis is needed. The majority of accounting papers reviewed use stakeholder theory as a notional guide or a point of reference devoid of particular content. There is therefore significant scope develop stronger theoretical connections between stakeholder inclusiveness and accounting theory and practice.

Thirdly, stakeholder theory is not a common frame of reference within the management accounting literature, which remains dominated by the corporate objective to maximize shareholder wealth. The shareholder-stakeholder orientation affects both the content of strategy and the strategic management accounting process which is central to financial decision-making in business. Nixon and Burns (2012) argued that in an environment of anti-business sentiment, corporate governance failures and the recent financial crisis, adherence to the classical strategic management accounting perspective, which assumes a stable and predictable environment, is questionable. A significant majority of the stakeholder theory informed management accounting papers are post-2003. Research indicates a growing awareness of the need to reassess traditional models of performance measurement, however, other management accounting theories and models, such as strategic management accounting techniques, capital investment appraisal and costing, would also benefit from being re-examined from a stakeholder theory perspective, highlighting an important area for future research. This is also an important area for management accounting education, which at best pays lip service to stakeholder theory, thereby reinforcing the shareholder primacy model in the minds of future managers.

Fourthly, there is evidence of a call for broader narratives that engage accounting with a questioning of the status quo of shareholder primacy to widen accountability. The accounting profession has a significant role to play in advancing this issue, given the power and influence that it has over professional and academic qualifications as well as corporate disclosure. A clearer understanding of stakeholder strategies deployed to influence accounting decision-makers (standard setters, the profession, academia, and corporate management) is needed in order to 
change managerial mind-set and expectations placed on the profession through the delivery of reports that are more useful and relevant to managers and stakeholders.

Finally, there is further scope for the critical school to develop novel ways of recording and prioritizing stakeholder claims that captures value creation and risk. This is a complex step-wise process which will require researchers to question: 1 . the basic objectives, assumptions, concepts and principles and qualitative characteristics adopted in accounting; 2. the reporting boundary of what should, and should not be reported on which extends the beyond the principles of ownership and control to encompass impact and implicit claims; 3. recognition principles that are capable of including stakeholder claims and value exchange activities; 4. Measurement techniques and metrics that go beyond monetary representation of transactions to capture impacts and value creation. 5. Disclosure practices which enhances, not hinders stakeholder communication and engagement.

This research agenda is multifaceted, challenging and thought provoking. Accounting researchers are in a strong position to promote stakeholder theory in practice as well as being in a privileged position to develop better ways of recognizing and fulfilling stakeholder rights.

\section{REFERENCES}

Adams, C.A. and Whelan, G. (2009). Conceptualising future change in corporate sustainability reporting. Accounting, Auditing \& Accountability Journal, 22(1), 118-143. 
Albrecht, W.S. and Sack, R.J. (2000). Accounting Education: Charting the Course throught a Perilous Future. Accounting Education Series, Vol. 16, American Accounting Association.

Alcaniz, L. Gomez-Bezares. F. and Roslender, F. (2011). Theoretical perspectives on intellectual capital: A backward look and a proposal for going forward, Accounting Forum, 35(2), 104-17.

Archel, P., Fernández, M., and Larrinaga, C. (2008). The organizational and operational boundaries of triple bottom line reporting: a survey. Environmental Management, 41, 106-17.

Armstrong, M.B. (1987). Moral development and accounting education. Journal of Accounting Education, 5, 27-43.

Axa, C. and Bjørnenak, T. (2005). Bundling and diffusion of management accounting innovations-the case of the balanced scorecard in Sweden, Management Accounting Research 16, 1-20.

Barone, E. Ranamagar, N. and Solomon, J.F. (2013). A Habermasian model of stakeholder (non) engagement and corporate (ir) responsibility reporting. Accounting Forum, 37(3), 163-81.

Barsky, N.P., Hussein, M.E. and Jablonsky, S.F. (1999). Shareholder and stakeholder value in corporate downsizing: The case of United Technologies Corporation. Accounting, Auditing \& Accountability Journal, 12(5), 583-604

Baskerville-Morley, R.F. (2004). Dangerous, Dominant, Dependent, or Definitive: Stakeholder Identification When the Profession Faces Major Transgressions. Accounting and the Public Interest, 4(1), 24-42.

Beattie, V. and Smith, S.J. (2012) Evaluating disclosure theory using the views of UK finance directors in the intellectual capital context, Accounting and 
Business Research, 42(5), 471-94.

Beattie, V. and Thomson, S.J. (2007). Lifting the lid on the use of content analysis to investigate intellectual capital disclosures. Accounting Forum, 31(2), 129-63.

Boesso, G. and Kumar, K. (2009). Stakeholder prioritization and reporting: Evidence from Italy and the US. Accounting Forum, 33(2), 165-75.

Bowen, R.M. DuCharme, L. and Shores, D. (1995). Stakeholders' implicit claims and accounting method choice. Journal of Accounting and Economics, 20(3), 25595.

Bowen, R.M.,Johnson, M.F.,Shevlin, T. and Shores,D. (1992) Determinants of the timing of quarterly earnings announcement. Journal of Accounting, Auditing and Finance, 7(4), 395-422.

Brennan, N.M. and Merkl-Davies, D.M. (2014). Rhetoric and argument in social and environmental reporting: the Dirty Laundry case. Accounting, Auditing \& Accountability Journal, 27(4), 602-33.

Breton, G. and Côté, L. (2006). Profit and the legitimacy of the Canadian banking industry. Accounting, Auditing \& Accountability Journal, 19(4), 512-39.

Brignall, S. and Ballantine, J. (2004). Strategic Enterprise Management Systems: new directions for research. Management Accounting Research, 15(2);22540.

Brown, R. and Jones, M. (2015). Mapping and exploring the topography of contemporary financial accounting research. The British Accounting Review, 47(3), 237-61.

Burgstahler, D. and Dichev, I. (1997). Earnings management to avoid earnings decreases and losses. Journal of Accounting and Economics, 24(1):99-126.

Calabrese, A. Costa, R. and Rosati, F. (2015). A feedback-based model for CSR assessment and materiality analysis. Accounting Forum, 39(4), 312-27. 
Camara, M., Chamorro, E., and Moreno, A. (2009). Stakeholder Reporting: The Spanish Tobacco Monopoly (1887-1986), European Accounting Review, 18(4), 697-717.

Carlsson-Wall, M., Kraus, K. and Messner, M. (2016). Performance measurement systems and the enactment of different institutional logics: insights from a football organization. Management Accounting Research, 32(September), 4561.

Connolly, C., Hyndman, N. and McConville, D. (2013). UK charity accounting: An exercise in widening stakeholder engagement. The British Accounting Review, 45(1), 58-69.

Cooper, S.M. and Owen, D.L. (2007). Corporate social reporting and stakeholder accountability: The missing link. Accounting, Organizations and Society, 32(7-8), 649-67.

Cormier, D., Magnan, M. and Van Velthoven, B. (2004). Environmental disclosure quality in large German companies: Economic incentives, public pressures or institutional conditions? European Accounting Review, 14(1), 3-39.

Deegan, C. and Blomquist, C. (2006). Stakeholder influence on corporate reporting: an exploration of the interaction between WWF-Australia and the Australian minerals industry. Accounting, Organizations and Society, 31, 343-72.

Deegan, C., and Rankin, M. (1997). The materiality of environmental information to users of annual reports. Accounting, Auditing \& Accountability Journal, 10(4), $562-83$.

Dillard, J.Roslender, R. (2011). Taking pluralism seriously: embedded moralities in management accounting and control systems, Critical Perspectives on Accounting, 22(2), 135-47.

Dong, S., Burritt, R. and Qan, W. (2014). Salient stakeholders in corporate social 
responsibility reporting by Chinese mining and minerals companies, Journal of Cleaner Production, 84(1), 59-69.

Durden, C. (2008). Towards a socially responsible management control system, Accounting, Auditing \& Accountability Journal, 21(5), 671-94.

Elijido-Ten, E.O. (2008). The case for reporting pro-active environmental initiatives: a Malaysian experiment on stakeholder influence strategies. Issues in Social and Environmental Accounting, 2(1), 36-60.

Elijido-Ten, E.O. (2011). Media coverage and voluntary environmental disclosures: A developing country exploratory experiment. Accounting Forum, 35(3), 139-57.

Elijido-Ten, E. O., Kloot, L. and Clarkson, P. (2010). Extending the application of stakeholder influence strategies to environmental disclosures: An exploratory study from a developing country. Accounting, Auditing \& Accountability Journal, 23(8), 1032-59.

Ellwood, S. (2009). Accounting for (a) public good: public healthcare in England.

Financial Accountability \& Management, 25(4), 411-33.

Ferguson, J., Collison, D.J., Power, D.M. and Stevenson, L.A. (2005). What are recommended accounting textbooks teaching students about corporate stakeholders? British Accounting Review, 37, 23-46.

Fisher, D.G., Swanson, D.L., and Schmidt, J.J. (2007). Accounting education lags CPE ethics requirements: implications for the profession and a call to action, Accounting Education: An International Journal, 16(4), 345-63.

Freeman, R.E., Harrison, J.S., Wicks, A.C., Parmar, B., and de Colle, S. (2010).

Stakeholder Theory: the State of the Art. Cambridge University Press.

Freeman, R.E. (1984). Strategic Management: A Stakeholder Approach. Boston: Pitman.

Friedman, A.L. and Miles, S. (2006). Stakeholders: Theory and Practice. Oxford: 
Oxford University Press.

Castilla-Polo, F. and Dolores Gallardo- Vázquez, D. (2016). The main topics of research on disclosures of intangible assets: a critical review. Accounting, Auditing \& Accountability Journal, 29(2), 323-56.

Clarke, T. (2014). The impact of financialisation on international corporate governance: the role of agency theory and maximising shareholder value. Law and Financial Markets Review, March, 39-51.

Geiger, M. and van der Laan Smith, J. (2010). The effect of institutional and cultural factors on the perceptions of earnings management. Journal of International Accounting Research, 9(2), 21-43.

Goddard, A. and Powell, J. (1994). Accountability and Accounting: Using Naturalistic Methodology to Enhance Organizational Control: A Case Study. Accounting, Auditing \& Accountability Journal, 7(2), 50-69.

Gray, R.H., Bebbington, J. and McPhail, K. (1994). Teaching ethics and the ethics of teaching: educating for immorality and a possible case for social and environmental accounting, Accounting Education: an International Journal, 3(1), 51-75.

Gray, R., Owen, D. and Adams, C.A. (1996). Accounting and Accountability: Changes and Challenges in Corporate Social and Environmental Reporting. London, Prentice Hall.

Gray, R., Kouhy, R. and Lavers, S. (1995). Corporate social and environmental reporting: A review of the literature and a longitudinal study of UK disclosure. Accounting, Auditing \& Accountability Journal, 8(2), 47-77.

Gray, R. Dey, C., Owen, D., Evans, R. and Zadek, S. (1997). Struggling with the praxis of social accounting: Stakeholders, accountability, audits and procedures. Accounting, Auditing \& Accountability, 10(3), 325-64. 
Grosser, K. and Moon, J. (2008). Developments in company reporting on workplace gender equality? A corporate social responsibility perspective. Accounting Forum, 32, 179-98.

Hall, M., Millo, Y. and Barman, E. (2015). Who and what really counts? Stakeholder prioritization and accounting for social value. Journal of Management Studies, 52(7), 907-934.

Harrison, J.S. and van der Laan Smith, J. (2015). Responsible Accounting for Stakeholders. Journal of Management Studies, 52(7), 935-60.

Hawley, D. (1991). Business ethics and social responsibility in finance instruction: An abdication of responsibility. Journal of Business Ethics, 10, 711-21.

Herbohn, K. Walker, J. and Loo, H.Y.M. (2014). Corporate social responsibility: the link between sustainability disclosure and sustainability performance, Abacus, $50(4), 422-59$.

Hines, R.D. (1988). Financial accounting: In communicating reality, we construct reality. Accounting, Organizations and Society, 13(3), 251-61.

Hui, K.W., Klasa, S. and Yeung,P.E.(2012). Corporate suppliers and customers and accounting conservatism. Journal of Accounting and Economics, 53, 115-35.

IASB (2010). The Conceptual Framework for Financial Reporting. IASB, London

Islam, M.A., and Deegan, C. (2008). Motivations for an organisation within a developing country to report social responsibility information: Evidence from Bangladesh. Accounting, Auditing and Accountability Journal, 21(6), 850-74.

Jensen, M.C. (2001). Value maximization, stakeholder theory, and the corporate objective function. Journal of Applied Corporate Finance, 14 (3), 8-21. 
Kamal, O., Brown, D., Sivabalan, P. and Sundin, H. (2015) Accounting information and shifting stakeholder salience: an industry level approach. Qualitative Research in Accounting \& Management, 12(2), 172-200.

Kaplan, R.S. and Norton, D.P. (2001). Transforming the balanced scorecard from performance measurement to strategic management: part I. Accounting Horizons, 15(1), 87-104.

Kwok, W.C.C. and Sharp, D (2005). Power and international accounting standard setting: Evidence from segment reporting and intangible assets projects, Accounting, Auditing \& Accountability Journal, 18(1), 74-99.

Länsiluoto, A. Järvenpää, M and Krumwiede, K. (2013). Conflicting interests but filtered key targets: Stakeholder and resource-dependency analyses at a University of Applied Sciences, Management Accounting, 24(3), 228-45.

Laux, C. and Leuz, C. (2009). The crisis of fair-value accounting: Making sense of the recent debate. Accounting, Organisations \& Society, 34, 826-34.

Leisen, A, Hoepner, A.G., Patten, D.M. and Figge, F. (2015). Does stakeholder pressure influence corporate GHG emissions reporting? Empirical evidence from Europe. Accounting, Auditing \& Accountability Journal, 28(7), 1047-74.

Leuz, C. and Verrecchia, R.E. (2000). The economic consequences of increased disclosure. Journal of Accounting Research, 38(Supplement), 91-124.

Li, P. and Tang, G. (2009). Performance measurement design within its organisational context-Evidence from China, Management Accounting Research, 20(3), 193-207. 
Magness, V. (2006). Strategic posture, financial performance and environmental disclosure: An empirical test of legitimacy theory. Accounting, Auditing \& Accountability Journal, 19(4), 540-63.

Mahadeo, J.D., Oogarah-Hanumana, V. and Soobaroyen, T. (2011). Changes in social and environmental reporting practices in an emerging economy (20042007): Exploring the relevance of stakeholder and legitimacy theories. Accounting Forum, 35(3), 158-75

Giacomo Manetti, G. and Bellucci, M. (2016). The use of social media for engaging stakeholders in sustainability reporting. Accounting, Auditing \& Accountability Journal, 29(6), 985-1011.

Mangos, N.C. and Lewis, N.R. (1995). A socio-economic paradigm for analysing managers' accounting choice behavior . Accounting, Auditing \& Accountability Journal, 8(1), 38-62.

Mattingly, J.E., Harrast, S.A. and Olsen, L. (2009). Governance implications of the effects of stakeholder management on financial reporting. Corporate Governance: The International Journal of Business in Society, 9(3), 271-82.

Merchant, K.A. (2006). Measuring general managers' performances: Market, accounting and combination-of-measures systems. Accounting, Auditing \& Accountability Journal, 19(6), 893-917.

Miles, S., Hammond, K. and Friedman, A.L. (2002). Social and Environmental Reporting and Ethical Investment, ACCA Research Report 77: Certified Accountants Educational Trust, London

Mitchell, R.K., Agle, B.R. and Wood, D.J. (1997). Towards a theory of stakeholder identification and salience: Defining the principle of who and what really counts. Academy of Management Review, 22, 853-86. 
Mitchell, R.K., Van Burren II, H., Greenwood, M. and Freeman, R.E. (2015). Stakeholder Inclusion and Accounting for Stakeholders, Journal of Management Studies, 52(7), 851-877.

Momin, M.A. (2013). Social and environmental NGOs' perceptions of corporate social disclosures: the case of Bangladesh, Accounting Forum, 37(2);150-61.

Moneva, J.M. and Llena,F. (2000). Environmental disclosures in the annual reports of large companies in Spain. European Accounting Review, 9(1), 7-29.

Murphy, T., O'Connell, V. and Ó hÓgartaigh, C. (2013). Discourses surrounding the evolution of the IASB/FASB Conceptual Framework: What they reveal about the "living law" of accounting. Accounting, Organizations and Society, 38(1), 72-91.

Näsi, S. and Näsi, J. (1996). Accounting and business economics traditions in Finland-from a practical discipline into a scientific subject and field of research. European Accounting Review, 6(2), 199-229.

Nielsen, C., Roslender, R. and Schaper, S. (2017). Explaining the demise of the intellectual capital statement in Denmark, Accounting, Auditing \& Accountability Journal, 30(1), 38-64.

Nixon, B. and Burns, J. (2012). The paradox of strategic management accounting, Management Accounting Research, 23(4);229-44.

Nobes, C.W. (1991). Cycles in UK standard setting. Accounting and Business Research, 21(83), 265-74.

Norris, G. and O'Dwyer, B. (2004). Motivating socially responsive decision making: the operation of management controls in a socially responsive organisation, The British Accounting Review, 36(2), 173-96. 
O'Dwyer, B., Unerman, J., and Bradley, J. (2005). Perceptions on the emergence and future development of corporate social disclosure in Ireland: Engaging the voices of nongovernmental organisations. Accounting, Auditing \& Accountability Journal, 18(1), 14-43.

O'Dwyer, B., Unerman, J., and Hession, E. (2005). User needs in sustainability reporting: perspective of stakeholders in Ireland. European Accounting Review, 14(4), 759-87.

O'Dwyer, B., Unerman, J. and Hession, E. (2004). The emergence and future development of Corporate Social Disclosure in Ireland: The perspectives of Non-Governmental Organisations. Accounting. Auditing and Accountability Journal, 18(1), 14-43.

Orij, R. (2010). Corporate social disclosures in the context of national cultures and stakeholder theory. Accounting, Auditing \& Accountability Journal, 23(7), 868-89.

Parker, L.D. (2005). Social and environmental accountability research: A view from the commentary box. Accounting, Auditing \& Accountability Journal, 18(6), 842-60.

Parker, L.D. (2007). A Commentary on 'Professionalizing Claims and the State of UK Professional Accounting Education: Some Evidence. Accounting Education: an International Journal, 16(1), 43-46.

Pérez, A.,López, C. and del García-De los Salmones, M. (2017). An empirical exploration of the link between reporting to stakeholders and corporate social responsibility reputation in the Spanish context. Accounting, Auditing \& Accountability Journal, 30(3). 668-98. 
Perry, J. and Nölke, A. (2006). The political economy of International Accounting Standards. Review of International Political Economy, 13(4), 559-86.

Prado-Lorenzo, J., Gallego-Alvarez, I., and Garcia-Sanchez, I. (2009). Stakeholder engagement and corporate social responsibility reporting: the ownership structure effect. Corporate Social Responsibility and Environmental Management, 16, 94-107.

Ringham, K. and Miles, S. (2018) The Boundary of Corporate Social Responsibility Reporting: The Case of the Airline Industry, Journal of Sustainable Tourism, forthcoming.

Roberts, R. W. (1992), 'Determinants of Corporate Social Responsibility Disclosure: An Application of Stakeholder Theory', Accounting, Organizations and Society, 17 (6), 595-612.

Roberts, R.W. and Mahoney, L. (2004). Stakeholder conceptions of the corporation: their meaning and influence in accounting research. Business Ethics Quarterly, 14(3), 399-431.

Rodrigue, M., Magnan, M. and Boulianne, E. (2013). Stakeholders' influence on environmental strategy and performance indicators: A managerial perspective, Management Accounting Research, 24(4), 301-16.

Scott, J.E.M., McKinnon, J.L. and Harrison, G.L. (2003). Cash to accrual and cash to accrual: A case study of financial reporting in two NSW hospitals 1857 to post-1975. Accounting, Auditing \& Accountability Journal, 16(1), 104-40.

Shaoul, J. (1998). Critical Financial Analysis and Accounting for Stakeholders. Critical Perspectives on Accounting, 9, 235-49. 
Soobaroyen, T., and Ntim, C.G. (2013). Social and Environmental Accounting as Symbolic and Substantive Means of Legitimation: The Case of HIVIAIDS Reporting in South Africa. Accounting Forum, 37(2), 92-109.

Spence, C. Husillos, J. and Correa-Ruiz, C. (2010). Cargo cult science and the death of politics: A critical review of social and environmental accounting research. Critical Perspectives on Accounting, 21(1), 76-89

Sundin, H., Granlund, M. and Brown, D.A. (2010). Balancing multiple competing objectives with a balanced scorecard, European Accounting Review, 19(2), 203-46.

Thomson, L. (1993). Reporting changes in the electricity supply industry and privatisation. Financial Accountability \& Management, 9(2), 131-57.

Thorne, L., Mahoney, L.S. and Manetti, G. (2014). Motivations for issuing standalone CSR reports: a survey of Canadian firms. Accounting, Auditing \& Accountability Journal, 27(4), 686-714.

Tilling, M.V. and Tilt, C.A. (2010). The edge of legitimacy. Accounting, Auditing \& Accountability Journal, 23(1), 55-81.

Tilt, C.A. (1994). The Influence of External Pressure Groups on Corporate Social Disclosure: Some Empirical Evidence. Accounting, Auditing and Accountability Journal, 7(4), 47-72.

Tooley, S., Hooks, J., and Basnan, N. (2010). Performance reporting by Malaysian local authorities; identifying stakeholder needs. Financial Accountability \& Management, 26(2), 103-133

Ullmann, A.A. (1985). Data in Search of a Theory: A Critical Examination of the Relationships among Social Performance, Social Disclosure, and Economic Performance of US. The Academy of Management Review, 10(3), 540-57. 
Unerman, J. and O'Dwyer, B. (2006). Theorising accountability for NGO advocacy. Accounting, Auditing \& Accountability Journal, 19(3), 349-76.

Van der Laan Smith, J., Adhikari, A. and Tondkar, R.H. (2005). Exploring differences in social disclosures internationally: A stakeholder perspective. Journal of Accounting and Public Policy, 24(2), 123-51.

Van der Laan Smith, J. Adhikari, A.,Tondkar, R.H. and Andrews, R.L. (2011). The impact of corporate social disclosure on investment behavior: A cross-national study. Journal of Accounting and Public Policy, 29(2), 177-92.

Williams,S.J. and Adams,C.A. (2013). Moral accounting? Employee disclosures from a stakeholder accountability perspective. Accounting, Auditing \& Accountability Journal, 26(3), 449-495.

Yongvanich, K. and Guthrie, J. (2005). Extended performance reporting: an examination of the Australian mining industry. Accounting Forum, 29(1), 103-119. 